\title{
The Cycas revoluta-Nostoc Symbiosis: Enzyme Activities of Nitrogen and Carbon Metabolism in the Cyanobiont
}

\author{
By PETER LINDBLAD, ${ }^{*}$ AMAR N. RAI ${ }^{2}$ AND BIRGITTA BERGMAN ${ }^{1}$ \\ ${ }^{1}$ Department of Physiological Botany, University of Uppsala, Box 540, S-751 21 Uppsala, Sweden \\ ${ }^{2}$ Department of Biochemistry, North-Eastern Hill University, Shillong 793014, India
}

(Received 21 October 1986; revised 8 January 1987)

\begin{abstract}
A comparative study was made of enzymes involved in nitrogen and carbon metabolism in the cyanobiont directly isolated from Cycas revoluta coralloid roots, and in the cultured isolate Nostoc 7422. The symbiotic Nostoc showed high activity of glutamine synthetase and glutamate synthase, the primary ammonia-assimilating enzyme system in cyanobacteria. Ammoniaassimilating glutamate dehydrogenase $(\mathrm{GDH})$ activity was undetectable, although the catabolic GDH activity was high. Both glutamate-oxaloacetic acid transaminase and malate dehydrogenase showed higher activities in the symbiotic Nostoc than in the cultured Nostoc strain. The symbiotic Nostoc did not fix $\mathrm{CO}_{2}$ in vivo although in cell-free extracts both ribulose1,5-bisphosphate carboxylase and phosphoribulokinase activities, similar to those in the cultured strain, were present.
\end{abstract}

\section{INTRODUCTION}

Among gymnosperms, cycads are the only group that form a symbiosis with a nitrogen-fixing organism. Filamentous heterocystous cyanobacteria of the genus Nostoc inhabit a cylindrical zone, intercellularly, in the cortex of cycad coralloid roots (Sprent, 1979; Lindblad et al., 1985). The fixed nitrogen is rapidly transported from the cyanobiont to the cycad (Bergersen et al., 1965; Renaut et al., 1975; Halliday \& Pate, 1976), although the form in which the fixed nitrogen is released and transported is unknown. Recently we obtained evidence (Lindblad \& Bergman, 1986) that, in contrast to the situation in most other symbiotic cyanobacterial symbioses, e.g. Anthoceros, Azolla and Peltigera (Stewart \& Rowell, 1977; Ray et al., 1978: Rai et al., 1981 c, 1983; Orr \& Haselkorn, 1982; Stewart et al., 1983; Meeks et al., 1985; Rowell et al., 1985), a product of ammonium assimilation, in addition to or instead of ammonia, is transferred from the cyanobacterial cells to the cycad.

The aim of the present work was to extend our studies of the enzymes involved in nitrogen metabolism and to obtain information regarding carbon metabolism in cyanobionts of the cycad Cycas revoluta.

\section{METHODS}

Organisms and growth. Coralloid roots from the cycad Cycas revoluta Thunb. were collected from plants growing in the Botanical Garden, University of Uppsala, Sweden. Cyanobacteria were carefully removed from the coralloid roots as described earlier (Lindblad \& Bergman, 1986; Rai et al., 1986). The washed cyanobacteria were resuspended in sterile BG-11 $1_{0}$ medium (Stanier et al., 1971) and used for the experiments within $1 \mathrm{~h}$.

Nostoc 7422 (ATCC 29132), originally isolated from Cycas, was obtained from the Pasteur Culture Collection, Paris, France. Axenic cultures were grown in BG-11 $1_{0}$ medium (Stanier et al., 1971) under continuous light at 90

Abbreviations: APT, aspartate-pyruvate aminotransferase; GDH, glutamate dehydrogenase: GOGAT, glutamate synthase; GOT, glutamate-oxalacetate aminotransferase; GPT, glutamate-pyruvate aminotransferase; GS, glutamine synthetase; $\mathrm{MDH}$, malate dehydrogenase; PEP, phosphoenolpyruvate: PRK, phosphoribulokinase; $\mathrm{RuBisCO}$, ribulose-1,5-bisphosphate carboxylase/oxygenase. 
$\mu$ mol photons $\mathrm{m}^{-2} \mathrm{~s}^{-1}$ [Philips $40 \mathrm{~W}$, TL 33 and $55(400-700 \mathrm{~nm})$ ] at $25^{\circ} \mathrm{C}$ and flushed with sterile air. The cultures were harvested after 6-8 d, washed with sterile BG-11 $1_{0}$ medium and resuspended in the same medium.

Preparation of cell-free extracts. The cyanobacterial cells were sedimented by centrifugation and resuspended in the following extraction buffers: for $\mathrm{GS}, 50 \mathrm{mM}$-Tris/ $\mathrm{HCl}, \mathrm{pH} 7 \cdot 5$, with additions of $10 \mathrm{~mm}$-glutamate, $5 \mathrm{~mm}-2$ mercaptoethanol, $5 \mathrm{mM}-\mathrm{MgCl}_{2}$ and $1 \mathrm{mM}-\mathrm{Na}_{2}$ EDTA (Lindblad \& Bergman, 1986); for GOGAT, $2 \mathrm{mM}-\mathrm{TES}$, pH 7.2 (Rai et al., 1981 a); for GDH, $50 \mathrm{mM}$-Tris/HCl, pH 7.5, containing $10 \mathrm{~mm}$-2-mercaptoethanol and $5 \mathrm{mM}$ -

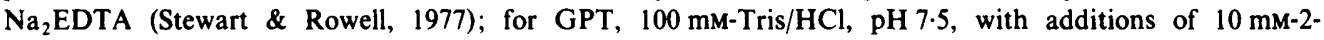
mercaptoethanol and $1 \mathrm{mM}-\mathrm{Na}_{2}$ EDTA; for APT, GOT and PEP carboxylase, pyruvate carboxylase and MDH, $50 \mathrm{~mm}$-Tris/ $\mathrm{HCl}, \mathrm{pH} 7.5$; and for RuBisCO and PRK, $10 \mathrm{~mm}$-Tris, $\mathrm{pH} \mathrm{8.0,} \mathrm{with} \mathrm{additions} \mathrm{of} 25 \mathrm{~mm}-\mathrm{NaHCO}_{3}$, $10 \mathrm{mM}-\mathrm{MgCl}_{2}$ and $1 \mathrm{mM}-\mathrm{Na}_{2}$ EDTA. After two or three passages through a French press at $110 \mathrm{MPa}$, the material was centrifuged $\left(35000 \mathrm{~g}\right.$ at $4^{\circ} \mathrm{C}$ for 30 min unless otherwise stated).

Enzyme assays. Glutamine synthetase (GS) was assayed as both $\mathrm{Mn}^{2+}$-dependent $\gamma$-glutamyltransferase activity (EC 2.3.2.2) and $\mathrm{Mg}^{2+}$-dependent biosynthetic activity (EC 6.3.1.2), as described by Sampaio et al. (1979). Glutamate synthase (GOGAT; EC 1.4.7.1) was assayed by measuring the formation of $\left[{ }^{14} \mathrm{C}\right]$ glutamate from $\left[{ }^{14} \mathrm{C}\right] \mathrm{glutamine}$ in the presence of the aminotransferase inhibitor aminooxyacetate (AOA). Preparation of cell-free extracts was as described by Rai et al. (1981a) except that the supernatants were dialysed overnight against the extraction buffer, instead of being passed through Sephadex G25. The reaction mixture, in a total volume of 0.7 $\mathrm{ml}$, was as described by Thomas $e t$ al. (1977). The reaction was stopped after $20 \mathrm{~min}$ by adding $0.7 \mathrm{ml} 100 \%$ acetone. The samples were chromatographed on TLC plates coated with $0.1 \mathrm{~mm}$ cellulose (Merck, Art. 5716) using iso-butanol/formic acid/water $(6: 1: 2$, by vol.) as the solvent system. The areas corresponding to the position of the glutamate standard were scraped off and counted in UniSolve 1 Scintillant (Zinsser Analytic), in an LKB Wallac 1217 Rackbeta scintillation spectrometer. For glutamate dehydrogenase (GDH), ammonia-assimilating activity (NADPH-dependent, EC 1.4.1.4) was measured as described by Stewart \& Rowell (1977) and catabolic activity (NADH-dependent, EC 1.4.1.2) by the same protocol except for the change of cofactor. Glutamatepyruvate aminotransferase (GPT; EC 2.6.1.2) was assayed as described by Jäger \& Weigel (1978), aspartatepyruvate aminotransferase (APT; EC 2.6.1.12) by the method of Herbert et al. (1978), and glutamate-oxalacetate aminotransferase (GOT; EC 2.6.1.1) as described by Rowell \& Stewart (1976). For ribulose-1,5-bisphosphate carboxylase/oxygenase (RuBisCO; EC 4.1.1.39), carboxylase activity was measured as described by McFadden $e t$ al. (1975); phosphoribulokinase (PRK ; EC 2.7.1.19) was assayed as described by Lanaras \& Codd (1981); for both assays, ${ }^{14} \mathrm{C}$ counting was done as described above. Phosphoenolpyruvate (PEP) carboxylase (EC 4.1.1.31), PEP carboxykinase (EC 4.1.1.49) and PEP carboxytransphosphorylase (EC 4.1.1.38) were all assayed as described by Rai $e t$ al. $(1981 b)$ except that the supernatants were dialysed overnight against the extraction buffer, instead of being passed through Sephadex G25. Pyruvate carboxylase (EC 4.1.1.1) and NADH-dependent malate dehydrogenase (MDH; EC 1.1.1.37) were assayed as described by Codd \& Stewart (1973).

In vivo $\mathrm{CO}_{2}$ fixation. The uptake of $\mathrm{CO}_{2}$ was followed using a gas chromatograph as described by Pettersson et al. (1985). The incorporation of ${ }^{14} \mathrm{C}$ was measured by incubating $2.0 \mathrm{ml}$ cyanobacterial cells in the presence of $\mathrm{NaH}^{14} \mathrm{CO}_{3}\left[2.0 \mu \mathrm{Ci} \mathrm{ml}^{-1}\right.$; specific activity $\left.56 \mathrm{mCi} \mathrm{mmol}^{-1}\left(2.07 \mathrm{GBq} \mathrm{mmol}{ }^{-1}\right)\right]$ at $28^{\circ} \mathrm{C}$ in the light $(70 \mu \mathrm{mol}$ photons $\mathrm{m}^{-2} \mathrm{~s}^{-1}$ ) or in darkness (preincubated in the dark for $30 \mathrm{~min}$ ). The incubations were terminated by adding $3.0 \mathrm{ml}$ acidified methanol and the incubation vials, containing cells, were left overnight without caps at room temperature in a fume cupboard to drive off unfixed ${ }^{14} \mathrm{CO}_{2} .{ }^{14} \mathrm{C}$-counting was then done as described above.

Chlorophyll $a$ and protein. Chlorophyll $a$ was determined according to Harborne (1973) and protein by the method of Bradford (1976) using bovine serum albumin as standard.

\section{RESULTS}

Cyanobacteria freshly isolated from coralloid roots of $C$. revoluta showed high in vitro activity of the ammonia-incorporating GS-GOGAT system, but NADPH-dependent (ammoniaassimilating) GDH activity was undetectable. However, catabolic GDH activity was present (Table 1). Among the transaminases tested, GPT, APT and GOT were all present (Table 1). GOT showed the highest activity, followed by APT and GPT. There were certain distinct differences in the enzyme activities of freshly isolated symbiotic Nostoc and the cultured Nostoc 7422: the symbiotic Nostoc showed a $75 \%$ higher GS activity, more than double catabolic GDH activity, over threefold higher GOT activity, and the presence of GPT (Table 1).

Net in vivo $\mathrm{CO}_{2}$-fixation, as assayed by gas chromatography or ${ }^{14} \mathrm{C}$ incorporation, was undetectable in the freshly isolated symbiotic Nostoc, in both light and dark conditions. In contrast, Nostoc 7422 showed high rates of $\mathrm{CO}_{2}$ fixation in light $[106.5 \mathrm{nmol} \mathrm{CO}$ fixed $(\mu \mathrm{g}$ chlorophyll $a)^{-1} \mathrm{~min}^{-1}$ or $257 \mathrm{nmol} \mathrm{H}^{14} \mathrm{CO}_{3}^{-}$incorporated $(\mu \mathrm{g} \text { chlorophyll } a)^{-1} \mathrm{~min}^{-1}$; means of duplicate experiments]. In spite of the absence of in vivo $\mathrm{CO}_{2}$-fixing ability, the symbiotic 
Table 1. In vitro activities of various nitrogen-assimilating enzymes in symbiotic Nostoc and Nostoc 7422

$\begin{array}{lcc}\quad \text { Enzyme } & \begin{array}{c}\text { Symbiotic } \\ \text { Nostoc }\end{array} & \begin{array}{c}\text { Nostoc } \\ 7422\end{array} \\ \text { GS } & & \\ \text { Transferase } & 1818.2 & 1054 \cdot 4 \\ \quad \text { Coupled biosynthetic } & 135.4 & 83.0 \\ \text { GOGAT } & 86.0 & 81.8 \\ \text { GDH } & & \\ \text { NADH-dependent } & 17.6 & 7 \cdot 4 \\ \text { NADPH-dependent } & \text { ND } & \text { ND } \\ \text { GPT } & 3.7 & \text { ND } \\ \text { APT } & 27.0 & 22.7 \\ \text { GOT } & 70.2 & 20.6\end{array}$

ND, Not detectable.

* The results are expressed as $\mathrm{nmol}$ product formed $\min ^{-1}\left(\mathrm{mg}\right.$ protein) ${ }^{-1}$ and are means of duplicate experiments.

Table 2. In vitro activities of RuBisCO,PRK, other $\mathrm{CO}_{2}$-fixing enzymes and $\mathrm{MDH}$ in symbiotic Nostoc and Nostoc 7422

\begin{tabular}{lcc} 
& \multicolumn{2}{c}{ Activity* } \\
\cline { 2 - 3 } \multicolumn{1}{c}{ Symbiotic } & Nostoc \\
Nostoc & 7422 \\
RuBisCO (carboxylase) & 279.4 & 321.7 \\
PRK & 153.2 & 163.6 \\
PEP carboxylase & $<1.1$ & 3.7 \\
PEP carboxykinase & $\mathrm{ND}$ & $<1.9$ \\
PEP carboxytransphosphorylase & $<1.8$ & $\mathrm{ND}$ \\
Pyruvate carboxylase & 3.5 & 4.2 \\
MDH (NADH-dependent) & 22.0 & 2.8
\end{tabular}

ND, Not detectabie.

* The results are expressed as nmol product formed $\min ^{-1}$ (mg protein) ${ }^{-1}$ and are means of duplicate experiments.

Nostoc, in cell-free preparations, showed RuBisCO carboxylase and PRK activities (Table 2). None of the other $\mathrm{CO}_{2}$-fixing enzymes tested showed any appreciable in vitro activity (Table 2), either in the symbiotic Nostoc or in Nostoc 7422. Interestingly, the symbiotic Nostoc showed at least seven times higher MDH (NADH-dependent) activity than Nostoc 7422 (Table 2).

\section{DISCUSSION}

Apparently there are at least two categories of nitrogen-fixing symbiotic cyanobacteria as regards ammonia-assimilating enzymes. First, there are those with a decreased GS activity, e.g. the cyanobacteria in Anthoceros, Azolla and Peltigera (Stewart \& Rowell, 1977; Ray et al., 1978; Haselkorn et al., 1980; Orr \& Haselkorn, 1982; Stewart et al., 1983; Meeks et al., 1985; Rowell et al., 1985). In Azolla and Peltigera the decrease in GS activity has been shown to be due to a decreased level of GS protein (Haselkorn et al., 1980; Orr \& Haselkorn, 1982; Stewart et al., 1983) resulting, at least in Azolla, from a reduction in the mRNA levels for GS protein (Nierzwicki-Bauer \& Haselkorn, 1986). In Peltigera, GS protein levels are particularly low in the heterocysts (Hällbom et al., 1986), the site of nitrogen fixation (Bergman et al., 1986). Furthermore, decreased GOGAT activities have also been noted in Azolla and Peltigera (Rai et $a l ., 1981 a$ ). In these symbioses the cyanobiont releases fixed nitrogen as ammonia because the 
levels of GS and GOGAT are insufficient to assimilate all the ammonia produced during nitrogen fixation. The ammonia thus released is assimilated by the eukaryotic partner (Ray et al., 1978; Rai et al., 1981 c, 1983; Stewart et al., 1983; Meeks et al., 1983, 1985; Rowell et al., 1985).

The second category is exemplified by the cycad symbiosis studied here. In $C$. revoluta the cyanobiont shows no decrease in in vitro GS activity (Lindblad \& Bergman, 1986; Rai et al., 1986; Table 1) or in vitro GOGAT activity (Table 1), nor is there any difference in the cellular/subcellular distribution of GS protein between the cyanobiont and the free-living nitrogen-fixing cyanobacterium (Lindblad \& Bergman, 1986). Full GS activity was also found in the cyanobiont of the cycad Zamia skinneri (Lindblad \& Bergman, 1986). Thus, the cyanobiont seems to be fully capable of assimilating all the ammonia produced by nitrogen fixation. However, the cyanobiont in cycad symbiosis does provide fixed nitrogen to the cycad plant (Bergersen et al., 1965; Renaut et al., 1975; Halliday \& Pate, 1976); the form in which the fixed nitrogen is released is not known, but in view of the high GS and GOGAT activities in the cyanobiont, it may be a product of ammonia assimilation.

Among the transaminases tested, GOT shows an increased activity in the symbiotic cyanobacteria of cycads. In contrast, no such increase is found in symbiotic cyanobacteria of the lichen Peltigera (Stewart \& Rowell, 1977; Rai et al., 1980, 1981 c). GOT requires oxaloacetic acid as one of the substrates. This may be provided by the action of $\mathrm{MDH}$, as we observed higher $\mathrm{MDH}$ activity in the cyanobiont of $C$. revoluta than in the cultured Nostoc strain. Thus, the possibility exists that these two enzymes might be involved in a malate-aspartate shuttle, transporting reducing equivalents from the cycad cells to the cyanobacterium as a substitute for those generated by light-requiring processes in free-living cyanobacteria.

The cyanobacteria in cycads are exceptional among symbiotic cyanobacteria in not being reached by light. This is manifested by the absence of in vivo $\mathrm{CO}_{2}$-fixation. Thus, the cyanobiont has to depend on heterotrophic carbon metabolism, the fixed carbon being provided by the cycad. A similar situation is found in symbiotic cyanobacteria of Anthoceros and Gunnera, where ${ }^{14} \mathrm{C}$ uptake and fixation are virtually absent in both light and dark (Rodgers \& Stewart, 1977; Silvester, 1976). In contrast, cyanobacteria in Azolla fix atmospheric $\mathrm{CO}_{2}$ (Ray et al., 1979; Peters et al., 1982; Peters \& Calvert, 1983) though the mRNA levels for RuBisCO are decreased (Nierzwicki-Bauer \& Haselkorn, 1986). Cyanobacteria in Peltigera aphthosa are also capable of fixing $\mathrm{CO}_{2}$ in the light and to a lower extent in the dark (Englund, 1977; Rai et al., 1983). In the latter case, carbon skeletons are provided by PEP carboxylase (Rai et al., 1981 b, 1983). It is not evident why $\mathrm{CO}_{2}$-fixation is lacking in the cyanobiont of cycads even when light is provided, since both RuBisCO (carboxylase) and the ribulose-1,5-bisphosphate-generating PRK were found in cell-free extracts. However, the absence of other enzymes of the Calvin cycle cannot be ruled out. Alternatively, the photosystems of the cyanobiont may be non-functional.

This study was supported by the Swedish Natural Science Research Council and SAREC. A. N. Rai thanks North-Eastern Hill University (Shillong, India) for grant of a Study Leave.

\section{REFERENCES}

Bergersen, F. J., Kennedy, G. S. \& Wittman, W. Englund, B. (1977). The physiology of the lichen (1965). Nitrogen fixation in the coralloid roots of Macrozamia communis L. Johnson. Australian Journal of Biological Sciences 18, 1135-1142.

Bergman, B., Lindblad, P. \& Rai, A. N. (1986). Nitrogenase in free-living and symbiotic cyanobacteria: immunoelectron microscopic localization. FEMS Microbiology Letters 35, 75-78.

BRADFORD, M. M. (1976). A rapid and sensitive method for the quantitation of microgram quantities of protein utilizing the principle of protein-dye binding. Analytical Biochemistry 72, 248-254.

CODD, G. A. \& STEWART, W. D. P. (1973). Pathways of glycollate metabolism in the blue-green alga Anabaena cylindrica. Archiv für Mikrobiologie 94, 11-28. Peltigera aphthosa with special reference to the bluegreen phycobiont (Nostoc sp.). Physiologia plantarum 41, 298-304.

Hällbom, L., Bergman, B. \& Rai, A. N. (1986). Immunogold localization of glutamine synthetase in the cyanobiont of the lichens Peltigera aphthosa and Peltigera canina. Lichen Physiology and Biochemistry 1, 27-34.

Halliday, J. \& Pate, J. S. (1976). Symbiotic nitrogen fixation by coralloid roots of the cycad Macrozamia riedlei: physiological characteristics and ecological significance. Australian Journal of Plant Physiology 3, 349-358.

Harborne, J. B. (1973). Recommended techniques, 
chlorophyll estimation. In Phytochemical Methods, pp. 205-207. London: Chapman \& Hall.

Haselkorn, R., Mazur, B., ORR, J., Rice, D., WoOd, N. \& RIPPKA, R. (1980). Heterocyst differentiation and nitrogen fixation in cyanobacteria (blue-green algae). In Nitrogen Fixation, vol. II, Symbiotic Associations and Cyanobacteria, pp. 259-278. Edited by W. E. Newton \& W. H. Orme-Johnson. Baltimore: University Park Press.

Herbert, R. A., Siefert, E. \& PfenNig, N. (1978). Nitrogen assimilation in Rhodopseudomonas acidophila. Archives of Microbiology 119, 1-5.

JÄGER, H. J. \& WEIGEL, H. J. (1978). Amino acid metabolism in lichens. Bryologist 81, 107-113.

LANaras, T. \& CODD, G. A. (1981). Ribulose 1,5bisphosphate carboxylase and polyhedral bodies of Chlorogloeopsis fritschii. Planta 153, 279-285.

LINDBLAD, P. \& BERGMAN, B. (1986). Glutamine synthetase: activity and localization in cyanobacteria of the cycads Cycas revoluta and Zamia skinneri. Planta 169, 1-7.

Lindblad, P., Bergman, B., Hofsten, A. V., HällBOM, L. \& NYLUND, J. E. (1985). The cyanobacterium-Zamia symbiosis: an ultrastructural study. New Phytologist 101, 707-716.

MCFAdDEN, B. A., TABita, F. R. \& KuehN, G. D. (1975). Ribulose diphosphate carboxylase from the hydrogen bacteria and Rhodospirillum rubrum. Methods in Enzymology 42, 461-472.

MEeks, J. C., ENDERLIN, C. S., WyCOFF, K. L., Chapman, J. S. \& Joseph, C. M. (1983). Assimilation of ${ }^{13} \mathrm{NH}_{4}^{+}$by Anthoceros grown with and without symbiotic Nostoc. Planta 153, 384-391.

Meeks, J. C., ENderlin, C. S., Joseph, C. M., Chapman, J. S. \& LollaR, M. W. L. (1985). Fixation of $\left[{ }^{13} \mathrm{~N}\right] \mathrm{N}_{2}$ and transfer of fixed nitrogen in the Anthoceros-Nostoc symbiotic association. Planta 164, 406-414.

NierzWicki-Bauer, S. A. \& Haselkorn, R. (1986). Differences in mRNA levels in Anabaena living freely or in symbiotic association with Azolla. EMBO Journal 5, 24-35.

ORR, J. \& HASELKORN, R. (1982). Regulation of glutamine synthetase activity and synthesis in freeliving and symbiotic Anabaena spp. Journal of Bacteriology 152, 626-635.

Peters, G. A. \& Calvert, H. E. (1983). The AzollaAnabaena symbiosis. In Algal Symbiosis, pp. 109145. Edited by L. J. Goff. Cambridge: Cambridge University Press.

Peters, G. A., Calvert, H. E., Kaplan, D., Ito, O. \& TOIA, R. E. (1982). The Azolla-Anabaena symbiosis: morphology, physiology and use. Israel Journal of Botany 31, 305-323.

Pettersson, A., Hällbom, L. \& Bergman, B. (1985). Physiological and structural responses of the cyanobacterium Anabaena cylindrica to aluminium. Physiologia plantarum 63, 153-158.

Rai, A. N., Rowell, P. \& Stewart, W. D. P. (1981a). Glutamate synthase activity in symbiotic cyanobacteria. Journal of General Microbiology 126, 515-518.

Rai, A. N., Rowell, P. \& Stewart, W. D. P. (1981 b). Nitrogenase activity and dark $\mathrm{CO}_{2}$ fixation in the lichen Peltigera aphthosa Willd. Planta 151, 256264.
Rai, A. N., Rowell, P. \& Stewart, W. D. P. (1981c). ${ }^{15} \mathrm{~N}_{2}$ incorporation and metabolism in the lichen Peltigera aphthosa Willd. Planta 152, 544-552.

Rai, A. N., Rowell, P. \& Stewart, W. D. P. (1983). Interactions between cyanobacterium and fungus during ${ }^{15} \mathrm{~N}_{2}$-incorporation and metabolism in the lichen Peltigera canina. Archives of Microbiology 134, 136-142.

Rai, A. N., Lindblad, P. \& Bergman, B. (1986). Absence of the glutamine-synthetase-linked methylammonium (ammonium)-transport system in the cyanobiont of Cycas-cyanobacterial symbiosis. Planta 169, 379-381

Ray, T. B., Peters, G. A., Tolja, R. E., JR \& Mayne, B. C. (1978). Azolla-Anabaena relationship. VII. Distribution of ammonia-assimilating enzymes, protein, and chlorophyll between host and symbiont. Plant Physiology 62, 463-467.

Ray, T. B., Mayne, B. C., Toia, R. E. \& Peters, G. A. (1979). Azolla-Anabaena relationship. VIII. Photosynthetic characterization of the association and individual partners. Plant Physiology 64, 791-795.

Renaut, J., Sasson, A., Pearson, H. W. \& Stewart, W. D. P. (1975). Nitrogen-fixing algae in Morocco. In Nitrogen Fixation by Free-living Micro-organisms (IBP Handbook no. 6), pp. 229-246. Edited by W. D. P. Stewart. Cambridge: Cambridge University Press.

Rodgers, G. A. \& Stewart, W. D. P. (1977). The cyanophyte-hepatic symbiosis. I. Morphology and physiology. New Phytologist 78, 441-458.

Rowell, P. \& Stewart, W. D. P. (1976). Alanine dehydrogenaseof the $\mathrm{N}_{2}$-fixingblue-greenalga Anabaena cylindrica. Archives of Microbiology 107, 115-124.

Rowell, P., RAI, A. N. \& StewarT, W. D. P. (1985). Studies on the nitrogen metabolism of the lichens Peltigera aphthosa and Peltigera canina. In Lichen Physiology and Cell Biology, pp. 145-160. Edited by D. H. Brown. New York: Plenum Press.

Sampaio, M. J. A. M., Rowell, P. \& Stewart, W. D. P. (1979). Purification and some properties of glutamine synthetase from the nitrogen-fixing cyanobacteria Anabaena cylindrica and a Nostoc sp. Journal of General Microbiology 111, 181-191.

SILVESTER, W. B. (1976). Endophyte adaption in Gunnera-Nostoc symbiosis. In Symbiotic Nitrogen Fixation in Plants, vol. 7, pp. 521-538. Edited by P.S. Nutman. Cambridge: Cambridge University Press.

SPRENT, J. (1979). The Biology of Nitrogen-fixing Organisms. London: McGraw-Hill.

Stanier, R. Y., Kunisawa, R., Mandel, M. \& CohenBazIRe, G. (1971). Purification and properties of unicellular blue-green algae (Order Chroococcales). Bacteriological Reviews 35, 171-205.

Stewart, W. D. P. \& Rowell, P. (1977). Modifications of nitrogen-fixing algae in lichen symbiosis. Nature, London 265, 371-372.

Stewart, W. D. P., Rowell, P. \& Rai, A. N. (1983). Cyanobacteria-eukaryotic plant symbioses. Annales de Microbiologie 134B, 205-228.

Thomas, J., Meeks, J. C., Wolk, C. P., Shaffer, P. W., Austin, S. M. \& ChIEN, W. S. (1977). Formation of glutamine from ${ }^{13} \mathrm{~N}$-ammonia, ${ }^{13} \mathrm{~N}$ dinitrogen and ${ }^{1+} \mathrm{C}$-glutamate by heterocysts isolated from Anabaena cylindrica. Journal of Bacteriology 129, 1545-1555. 